\title{
Private Funding
}

National Cancer Institute

\section{Source}

National Cancer Institute. Private Funding. NCI Thesaurus. Code C102432.

Money available for projects or products in the private sector that does not include government contribution, grants or contracts. 